\title{
Editorial - Urban Planning in China
}

Concepts, Actors, and Projects

\section{Nicolas Douay}

Translator. Michael Black

\section{OpenEdition}

\section{Journals}

\section{Electronic version}

URL: http://journals.openedition.org/chinaperspectives/7169

DOI: 10.4000/chinaperspectives.7169

ISSN: 1996-4617

\section{Publisher}

Centre d'étude français sur la Chine contemporaine

\section{Printed version}

Date of publication: 1 March 2017

Number of pages: $3-5$

ISSN: 2070-3449

\section{Electronic reference}

Nicolas Douay, «Editorial - Urban Planning in China », China Perspectives [Online], 2017/1 | 2017, Online since 01 March 2017, connection on 23 September 2020. URL : http://journals.openedition.org/ chinaperspectives/7169; DOI : https://doi.org/10.4000/chinaperspectives.7169 


\title{
Editorial - Urban Planning in China
}

\author{
Concepts, Actors, and Projects
}

\author{
NICOLAS DOUAY
}

$\mathrm{T}$ he practice of planning, which can be defined as "the deliberate action of a social group to organise, or even transform, space with the aim of generating positive effects on society," (1) has a long history in China. Thus, in ancient times, cities were traditionally surrounded by walls and laid out according to rules of urban composition inspired by geomancy and fengshui. The more contemporary period is characterised by the influence of the West as a source of inspiration. During the 1920s and 1930s, the Nationalists pursued a policy of urban-oriented (2) modernisation, in accordance with the canons of rational planning that characterised European and American cities at that time.

Beginning in 1949, ${ }^{(3)}$ planning policies were influenced by socialist theories of Soviet origin with, for example, centralism and planning committees. These policies materialised in particular in a form of monumental urbanism. At that time, the regime focused on the development of the countryside, and limited the growth of urban spaces for more than three decades. Development was organised around five-year plans, with the principal mission of encouraging and supporting the development of industry. Urban policies therefore aimed to close cities in order to limit their role to production rather than consumption. After the failure of the Great Leap Forward, planning was accused of having drawn up unrealistic plans and then completely rejected them in the context of the Cultural Revolution, between 1966 and 1976. Plans were thus abandoned in both large and small towns. Not until 1978 and the opening up of China did the practice of planning gradually reappear in a formal manner.

The process of opening up had the effect of changing the balance between the urban and the rural. The trend towards urbanisation ${ }^{(4)}$ accelerated, with the urban population rising from $19 \%$ of the total population in 1980, to $54.77 \%$ in 2014. According to 2010 census data, the country has 193 metropolitan areas with a population of over one million inhabitants, and six metropolises that exceed 10 million: Shanghai, Beijing, Chongqing, Tianjin, Guangzhou, and Shenzhen. In a context of economic growth that remains sustained despite the slowdown, urbanisation is expected to continue over the next decade, and by 2025 it is estimated that there will be 221 metropolitan areas with more than one million inhabitants.

This urbanisation is one of the spatial manifestations of the transition context and has economic, social, and environmental dimensions. ${ }^{(5)}$ There is, therefore, a strong relationship between urbanisation and spatial planning, with urbanisation being based on planning policies that attempt to regulate it and, conversely, urbanisation policies favouring the pursuit of urbanisation. In this context, some authors, such as Fulong $\mathrm{Wu}^{\left({ }^{(}\right)}$even put forward the idea that planning, and more precisely the production of plans, have become key elements in the process of urbanisation and economic growth. Thus, while in the West planning has often been seen by supporters of neoliberalism as the enemy of economic development, in the Chinese case, Fulong Wu presents it as its best ally. ${ }^{(7)}$ Indeed, from 1984 , the date of urban reform and the adoption of regulation of town planning, a more formal practice of planning returned. (8) More precisely, these interventions were then closer to spatial planning, which can be defined as a politico-technical device designed to coordinate public and private initiatives and development actions in a given territory, in particular through the production of plans and projects. ${ }^{(9)}$ Development would thus be at the interface between the state and the market and would provide the essential support for growth by developing the land, which would become the base of the economic expansion of the country. Under the Western influence of the strategic current, the whole planning system adapted itself to the emergence of entrepreneurship and aimed to promote growth by following the canons of neoliberal prescriptions. ${ }^{(10)}$ This strategic approach was reflected in a proliferation of plans without any legal value, whose purpose was to promote development from a territorial marketing perspective.

More recent developments in urban planning and development in China refer to the global trend towards more sustainable development. In accordance with $\mathrm{Hu}$ jintao's idea of a "harmonious society," the concept of "harmonious urbanisation" was presented in Nanjing at the fourth World Urban Forum of the UN in 2008 and at the World Expo in Shanghai in 2010. Concretely, many eco-city projects are developing on the outskirts of major

1. Frédéric Santamaria, "Aménagement" (Planning), Hypergéo, http://www.hypergeo.eu/spip.php?article474 (Accessed on 11 January 2017).

2. Joseph W. Esherick (ed.), Remaking the Chinese City: Modernity and National Identity, 1900-1950, Honolulu, University of Hawaii, 2000.

3. Léon Hoa, Reconstruire la Chine: trente ans d'urbanisme, 1949-1979 (Rebuilding China: thirty years of city planning), Paris, Le Moniteur, 1981; Wing-Shing Tang, "Urban Land Development under Socialism: China between 1949 and 1977," International Journal of Urban and Regional Research, Vol. 18, No. 3, 1994, pp. 392-415.

4. Jean-François Doulet, La ville "made in China" (The City "made in China") Paris, B2, 2013; Thierry Sanjuan, "La fin des trois Chine?" (The end of the three Chinas?), Géoconfluences, 14 February 2016, http://geoconfluences.ens-lyon.fr/informations-scientifiques/dossiers-regionaux/lachine/articles-scientifiques/la-fin-des-trois-chine (Accessed on 11 January 2017); Victor Sit, Chinese City and Urbanism: Evolution and Development, Singapore, World Scientific, 2010; François Gipouloux (ed.), China's Urban Century: Governance, Environment and Socio-Economic Imperatives, Cheltenham, UK, Northampton, MA, Edward Elgar Publishing, 2015; Yan Song and Chengri Ding (eds.), Urbanisation in China: Critical Issues in an Era of Rapid Growth, Cambridge (MA), Lincoln Institute of Land Policy, 2007.

5. OECD, Environmental Performance Reviews: China, Paris, OECD, 2007, http://www.oecd.org/ china/environmentalperformancereviewschina2007.htm (Accessed on 11 January 2017); Thierry Sanjuan, Atlas de la Chine. Une puissance sous tension (Atlas of China. A Power under strain), Paris, Autrement, 2015.

6. Fulong Wu, Planning for Growth Urban and Regional Planning in China, New York, Routledge, 2015.

7. Ibid.

8. Michael Leaf and Li Hou, "The 'Third Spring' of Urban Planning in China. The Resurrection of Professional Planning in the Post-Mao Era," China Information, Vol. 20, No. 3, 2006, pp. 553-585.

9. Pierre Merlin and Françoise Choay, Dictionnaire de l'urbanisme et de l'aménagement (Dictionary of city and regional planning), Paris, Presses Universitaires de France, 2010; Laurent Devisme, "Planification" (Planning) in Jacques Lévy and Michel Lussault (eds.), Dictionnaire de la géographie et de l'espace des sociétés (Dictionary of the geography and space of societies), Paris, Belin, 2003, pp. $720-721$

10. Fulong Wu, "China's Changing Urban Governance in the Transition: Towards a more market-oriented economy," Urban Studies, Vol. 39, No. 7, 2002, pp. 1071-1093; Anthony A. Yeh and Fulong Wu, "The Transformation of the Urban Planning System from a Centrally-planned to Transitional Economy," Progress in Planning, Vol. 51, 1999, pp. 167-252. 
metropolises. ${ }^{(11)}$ However, the reality of the practice shows that these projects are subject to the contingencies of local political power and to the criteria of real estate profitability of the investors. In many cases, they are still struggling to provide credible answers to environmental and climatic issues, particularly with regard to the recurring episodes of air pollution.

Finally, while the collaborative approach is now the dominant paradigm in the theories of Western spatial planning, ${ }^{12)}$ Chinese practice is marked by a downward planning system with a concentration of power at higher levels. Development thus often remains the prerogative of a small circle of public and private actors in "pro-growth socialist coalitions," (13) which bring together Communist Party leaders, municipal officials, entrepreneurs, and investors - the boundaries between these different groups being necessarily fluid and shifting - around an urban project aimed at the appreciation of the value of land and at economic growth. While the Internet sometimes allows controversy in the public domain, ${ }^{14)}$ public participation is generally limited to information, without the interactions allowing any form of accountability, much less public debate, in the shaping and implementation of development projects. ${ }^{(15)}$ The aim of this issue is to observe the role played by spatial planning and urban planning in contemporary Chinese changes, and to identify theoretical and practical transformations by focusing on the concepts, actors, and projects of urban planning. First, it is a matter of questioning the evolution of the styles of planning ${ }^{(16)}$ and of the concepts that underpin action. These are classic questions in the field of planning, because they make it possible to question its meaning. In the Chinese context, this raises the question of going beyond the traditional planning model and of the advent of new styles of planning that could become more strategic in order to follow neoliberal prescriptions, more collaborative in order to better build consensus among actors, more sustainable in order to respond to environmental emergencies, and even more intelligent ${ }^{(17)}$ in the context of the shift towards digitalisation. Secondly, it is a matter of observing the concrete modalities of these voluntary transformations of space. From the point of view of procedures, attention is focused on the various actors and their power relations, as well as their concepts and methods in the process of making the city. Moreover, from the point of view of the substance of the installations, attention is focused on objects (metropolitan plans, large urban projects, development of public spaces, sectoral policies on transport, environment, heritage, etc.), and the implementation challenges of projects and plans. The interest of this dossier is to try to cross-reference these three dimensions in order to provide a more detailed understanding of this central element in contemporary Chinese transformations.

In order to illustrate these major changes in urban planning and to account for the diversity of practice at all levels of Chinese territory, the nine articles in this dossier are organised around four clusters. The first set of articles deals with the return of urbanism and its structuring as a field of practice. The article by Lisa Melcher identifies key concepts and techniques of planning through analysis of the content of the main textbooks used for small town development. It demonstrates that the dominant norms and paradigms emphasise modernisation according to a technical approach. It also highlights the discrepancy between the importance of the environmental and heritage issues that textbooks advocate and the lack of interest that professionals ultimately take in their practice, notably because of a lack of resources. Next, the text by Martin Tzou, Du Shu, and Liu Lidan analyses the policies of integrated planning (duoguiheyi). In the name of greater coherence in public policy, these are aimed at integrating plans drawn up by several ministries. However, this already technically complex process is encountering a power struggle between administrations, making it difficult to implement.

The second group of articles questions the implementation of sustainable urban development. Rémi Curien looks back on more than 20 years of SinoSingaporean cooperation with the analysis of two projects, from the industrial park project in Suzhou to that of the eco-city of Tianjin. He shows how the incorporation of the Singapore model in these operations offers a way to combine economic development with urban planning. However, these advances have been made possible by capacities for political and financial action that remain exceptional and have major limitations in terms of environmental sobriety and urban and social integration. Next, the article by Giulia C. Romano applies the theories of organisational learning to the study of the transfers of the eco-city concept to China. It shows that the contribution of international cooperation to the evolution of local urban development practices can be greatly hampered by existing institutional and organisational structures. As a result, the reform process may present characteristics of instability and fragility, leading to selective, gradual, and uncertain introduction of new approaches to city development. Finally, the author calls for a rethink of the impact of this cooperation over the longer term. To round off these questions about sustainable urban development, the article by Daniele Brombal and Angela Moriggi focuses on institutional change in sustainable urban development. Their analysis focuses on the case of the Lihu Lake Basin in Wuxi City, Jiangsu Province, where the integration of environmental management into urban planning led to the creation of a new organisational field centred on the issue of the sustainable development of urban areas with distinct regulatory, normative, and cognitive aspects.

11. Rémi Curien, "Chinese Urban Planning. Environmentalising a hyper-functionalist machine?", China Perspectives, No. 2014-3, 2014, pp. 23-31; Rémi Curien, "L'éco-cité de Tianjin: innovations et limites d'une conception sino-singapourienne d'une ville durable" (The Ecocity of Tianjin: Innovations and limitations of a Sino-Singaporean conception of a sustainable city), Métropolitiques, 30 March 2016, http://www.metropolitiques.eu/L-eco-cite-de-Tianjin-innovations.html (Accessed on 11 January 2017); Nicolas Douay and Thuy Cory. "Développement urbain durable en Chine: entre apprentissage et mirage marketing" (Sustainable urban development in China: Between learning and mirage marketing), in Michel Hubert, Paul Lewis, and Michel Max Raynaud (eds.), Les Grands Projets urbains. Territoires, acteurs et stratégies (Major urban projects: Territories, actors and strategies), Montréal, Presses de l'université de Montréal, 2014 , pp. 239-262; Carine Henriot, "Les politiques chinoises de villes nouvelles: trajectoire et ajustements de l'action publique urbaine à Shanghai" (Chinese new city policies: Trajectory and adjustments in urban public action in Shanghai), Géocarrefour, No. 90/1, 2015, pp. 27-38; Jean-François Doulet, "L'urbanisme chinois et l'émergence du modèle 'intégrationniste'" (Chinese city planning and the emergence of the "integrationist" model), Métropolitiques, 27 April 2015, http://www.metropolitiques.eu/L-urbanisme-chinois-et-l-emergence.html (Accessed on 11 January 2017).

12. Judith Innes, "Planning Theory's Emerging Paradigm: Communicative Action and Interactive Practice," Journal of Planning Education and Research, Vol. 14, No. 3, 1995, pp. 183-190.

13. Tingwei Zhang, "Urban Development and a Socialist Pro-growth Coalition in Shanghai," Urban Affairs Review, Vol. 37, No. 4, 2002, pp. 475-499.

14. Yao Cheng, "Collaborative Planning in the Network: Consensus seeking in urban planning issues on the Internet - the case of China," Planning Theory, Vol. 12, No. 4, 2013, pp. 351-368; Nicolas Douay, "Urban Planning and Cyber-Citizenry in China," China Perspectives, No. 2011/1, 2011, pp. 77-79.

15. Tingwei Zhang, "Decentralisation, Localisation, and the Emergence of a Quasi-Participation Decision-Making Structure in Urban Development in Shanghai," International Planning Studies, Vol. 7, No. 4, 2002, pp. 303-323

16. Daniel B. Abramson, "Urban Planning in China: Continuity and Change: What the future holds may surprise you," Journal of the American Planning Association, Vol. 72, No. 2, 2006, pp. 197-215; Nicolas Douay, "Shanghai: Urban Planning Styles in Evolution. Emergence of a 'Harmonious Urbanisation'?", China Perspectives, No. 2008/4, 2008, pp. 16-25; John Friedmann, China's Urban Transition, Minneapolis, University of Minnesota Press, 2005; Tingwei Zhang, "Developing the Chinese Planning Theory - Planning Theory in the Age of Diversity," Conference paper "ACSP AESOP - joint congress," Chicago, 2008, Fulong Wu, 2015, op. cit.

17. Nicolas Douay and Carine Henriot, "La Chine à l'heure des villes intelligentes" (China in the era of intelligent cities), L'information géographique, "Aménagement et urbanisme en Chine" (Geographical Information, "Layout and city planning in China"), No. 80, 2016, pp. 89-104. 
The third set of articles examines the production of urban space from the point of view of financial and real estate networks. In his article, Thierry Theurillat focuses on the financing of urban growth based on land. The case of Qujing, a small town in Yunnan, shows the multiple interactions that take place between local government, state and private real estate companies, and local banks, in order to produce urban infrastructure that meets "collective and public" needs, and real estate whose character is "private and individual." It highlights the indispensable role of capital in enabling the production of urban space in China. Mingye Li's article focuses on the evolution of Chinese ghost towns and questions the necessary paradigm shifts in urban planning geared towards achieving growth objectives. The Changzhou case study illustrates the phenomena of over-construction in a context of entrepreneurial governance focused on urban expansion.

The fourth and final cluster deals with the realisation of urban projects, with two articles on the metropolis of Shanghai. The article by Carine Henriot and Martin Minost analyses the urban production and social reception of a district of Western architecture. Through the "Thames Town" case, the authors report on the circulation of internationalised urban planning models and practices and the local learning of public-private growth coalitions. The authors also point out that this town planning creation, with its borrowed architectural forms, raises questions about both its morphology and its social reception/production. Also in Shanghai, Brigitte Bertoncello, Lély Tan, and Jian Zhuo present the case of the Gubei Pedestrian Promenade (GPP), which aims to transform an old road into a pedestrian zone favourable to the development of a neighbourhood life. The article aims to show that development produced on a local scale - far from the monumental develop- ments shown in the media - can constitute a strong point of urban space production, an example that makes a contribution to the quest for identity of a modern city concerned with sustainability of its interventions.

This special dossier presents various aspects of the practice of urban planning in China, focusing on the main concepts and models that underpin action, on a group of actors involved in these processes, and on various concrete projects to transform space. However, given the complexity and wide range of urban planning practice in China, it would be difficult to claim exhaustiveness. Thus, it was not possible to include articles relating to the cases of Hong Kong and Taiwan. These could have illustrated a greater diversity of practices, or even questioned the circulation of models in the Chinese world. Moreover, the study of actors and processes could have been the subject of articles dealing with citizen mobilisation around issues of development, or processes of decentralisation and reconfiguration of levels of power. Likewise, the study of the substance of development projects could have focused on heritage or transport issues, or the impact of new technologies. Nonetheless, we hope that the subjects dealt with by the articles in this dossier make it possible to better understand this major phenomenon in the evolution of contemporary China.

\section{Translated by Michael Black}

Nicolas Douay is Associate Professor of urbanism at the Université Paris-Diderot (UMR Géographie-Cités) and is currently on assignment with the CNRS at the French Center for Research on Contemporary China (CEFC) (ndouay@cefc.com.hk). 